\title{
Youth Restiveness in Nigeria: Implications on Sustainable National Development
}

\author{
Raymond Akpokighe \& Austine Ejovi \\ http://dx.doi./org/10.4314/ujah.v21i3.4
}

\begin{abstract}
Youth restiveness has become a topical issue for discussion in the social, economic and polity domain in Nigeria. It is a fact that Nigeria cannot thrive and progress significantly with youths who are restive. Nigeria's peace, security and corporate existence as a nation is threatened because of the prevalence of this phenomenon. The causes of youth restiveness are connected to unemployment, lack of basic and inadequate infrastructural facilities and inadequate social amenities amongst others. The spiralling effect of youth restiveness are evident in Nigeria as ethnic militia, kidnapping, cultism, armed robbery, agitations and involvement in social insecurity. The causes and effects of youth restiveness have promoted uncertainties which have led to failure, fear and underdevelopment of most sectors in the Nigeria. The conflict theory explains that threatening events such as wars, revolution, domestic violence and others are as a result of competition and limited resources. Unfortunately, Nigeria's government has not done enough by providing basic facilities, employment opportunities and effective empowerment programmes for the youths to be gainfully employed. This study holds unto the premise that in order to control youths in Nigeria, their skills, talents and education must be recognized, encouraged and channelled to the right sector in the society for growth, sustainable development and national peace. This paper reviewed the arguments surrounding youth restiveness in Nigeria alongside some recommendations on how the government could effectively be organized and responsible to counter the growing rate of youth restiveness in Nigeria.
\end{abstract}

Keywords: Causes, Effects, Control Youth, Peace 


\section{Introduction}

Youth is a period of change from the reliance of childhood to adulthood's freedom and being aware of the need to work with other members of the society to help achieve the aims and objectives of the society (United Nations Youth, 2019). At this stage, the youths with or without education are determined to have sustainable employment to help them meet their essential needs. However, the youths in the society are increasing, thereby leading to high unemployment rates and increased level of dependency. It is eminent to state that strength, labour and efforts of youths are assets to a functional social environment. Positive contributions help to promote growth and development of a place.

In every society, youthfulness is very important. The roles of youths are very many as they include maintenance of law and order, preservation of societal culture, promoting knowledge, partaking in communal politics, developing projects, participating in cultural festivals, involving in local sports events, engaging themselves in traditional marriages as well as funerals amongst others.

Youth's restiveness has led to the inactiveness of the youths to tackle problems, discharge responsibilities effectively and inability to meet goals of the society. Elegbeleye (2005) identified one of the factors that can lead to youth restiveness as "perceived victimization arising from economic exploitation". In modern times, the inability of youth to exercise self-control to issues that has led to conflict and protest has been narrowed down to scarcity and unequal distribution of natural resources, non-recognition, marginalizing their society, having feelings of discontentment, non favourable government laws, lack of quality education and high rate of employment.

Nsidibe et al (2017) stated that restiveness orchestrated by youth has been on the increase in almost all communities in Nigeria, most especially in recent past. Since the inception of our nascent democracy, there has been a proliferation of unravelled violence, 
killing of innocent people and most recently the insurgence in North East, militancy in the Niger Delta and marauding attack by Fulani's herdsmen across the country." There is usually a state of anarchy, destruction of lives and properties when youths are not satisfied. At this stage, the actions of the youths are regarded as criminal in nature because their expressions are usually violent and disrupt law and order as well as various activities in the societies. In most cases, it takes the use of force such as involving the police to keep the violence of the youths in check.

The era of oil boom in the Niger Delta region was the point where youths felt that they should be involved in the oil industries because the industry had facilities in their various communities. This left the oil companies handicap as a lot of them do not have the necessary qualifications, skills and knowledge to get employed in the oil industry. Nevertheless, they refused to direct their focus to other areas of self employment such as agriculture and other empowerment programmes. The focus on the monies paid to the few community youths employed in the area was what gave them hope that all will be employed and played same. Due to lack of enlightenment, exposure, education and knowledge, they failed to realize that the oil industry cannot accommodate all especially those without skills and knowledge.

The inability of Nigeria youths to adjust to their environment, crave for wealth and lust for recognition are problems they are confronted with. Hence, the youths have become involved in kidnapping, vandalization of oil pipelines, increase rate of armed robbery, bomb attacks, thuggery, murder, destruction of properties, increased insecurity and crude oil theft (bunkering) to mention but a few. The focus of this paper is to identify, analyze and find solution to the problems of the youths to help curb youth restiveness.

The youths sometimes protect their societies through the use of youth restiveness. At times, competing management style is 
adopted by the youth to achieve their objectives. It involves being very assertive and uncooperative. They want to satisfy their interest as well as those of their societies and are willing to do so at the other party's expense, be it the government. It is a phenomenon which in practice has led to a near breakdown of law and order, low productivity due to disruption of production activities, increasing crime rate, intra-ethnic hostilities, and harassment of prospective developers and other criminal tendencies.

This plague of youth restiveness has been in existence for long, and permanent solution to it is yet to be found. This devastating occurrence of youth restiveness has also led to ethnic crisis and low productivity and will lead to instability in communities. Concentration here should be on the cause of youth restiveness, its effects and solutions

\section{Conceptualization of Terms}

The five major terms used in this study are Causes, Effects, Control, Youth and Peace. There is the need to have an understanding of these terms before relating them to Youth Restiveness and how Public Peace can be enhanced.

Causes: Cause is the reason why something, situations and circumstances occur. According to Steemit (2018), the causes of youth restiveness are attributed to several factors. Amongst the causes of youth restiveness is illiteracy.

Effects: It is a positive or negative change which is an outcome or result of an act or other reasons. The effect of youth restiveness usually produces negative change. Such change includes destruction of lives and properties amongst others. Ikpa (2013) sees these negative developments as unfortunate. 
Control: Control is the power to influence or direct people's behaviour towards achieving a set goal (Google Dictionary, 2019). Control is synonymous to solution. The factors that lead to the control of youth restiveness are numerous. When goods and services are available and are equitably distributed, it leads to societal stability. It prevents situations from degenerating.

Youth: It is a period of your life when you are young or the state of being young (Cambridge Dictionary, 2019). It is a phase or transition from dependence to independence (Nsidibe et al, 2017). This stage requires the youth to be controlled emotionally, psychologically, in their attitudes and behaviour to attain relative peace.

Peace: It means freedom from disturbance: tranquility (Google Dictionary, 2019). When youth restiveness is curbed, there will be freedom from disturbances such as vandalisation of properties. The relationships of the above concepts to youth restiveness cannot be overemphasized. Hence, the need has arisen to study the causes, effect and control of youth restiveness in order to achieve significant peace in the society.

Methodology: In the course of this study, relevant literatures on Youth Restiveness were utilized to analyze the Causes, Effect and Control of Youth Restiveness in Enhancing Public Peace. Appropriate observations were used as phenomenon and information that added the objectives of the study. Hence, the method adopted was qualitative in nature.

\section{Theoretical Framework}

The problems of inequitable distribution of national resources, marginalization, poverty and unemployment have fostered the youths' dive into restiveness thereby creating instability in the society system. 
Two theories were adopted in this study to proffer an explanation for youth restiveness. The theories are conflict and strain theory. Crossman, 2019 noted that:

Conflict Theory states that tension and conflict arise when resource, states and power are unevenly distributed between groups in society and that this conflict becomes the engine for social change. In this context, power can be understood as control of material resources and accumulated wealth, control of politics and institutions that make up society, and one's social status relative to others (determined not by class but by race, gender, sexuality, culture and religion among other things".

The classic strain theory focuses on deprive youth. The inability for youths to accomplish set goals forces them into crime (Britannica, 2019). Merton (1930) stated that pressures derived from social factors such as lack of income or lack of quality education drives individuals to commit crimes. Crossman also avers that:

Strain Theory explains deviant behaviour as an inevitable outcome or the strain individual experience when society does not provide adequate and approved means of achieving culturally valued goals. For example, when a society places cultural value on economic success and wealth, but only provides legally sanctioned means for a small portion of the population to achieve this goals, those excluded may turn to unconventional or criminal means of attaining them (Crossman, 2019).

In respect to the above, government should treat all fairly. Segregation, deprivation, misappropriation and embezzlement of funds should be curbed to avoid criminality and underdevelopment in societies. Basically, economic, political, education, social, medical 
and technological needs of the masses are inevitable to enhance development and growth in societies.

\section{The Causes of Youth Restiveness}

The causes of youth restiveness are numerous. It is disturbing that most youths do not want to take up responsibilities anymore. They always look for the easy way out which is usually unlawful and unprofitable. In the past, most youths were seen to be involved in farm work, trading, helping out in house chores and other decent task. Today, youths see themselves as high and above such responsibilities, even when they do not have the required criteria for a white-collar job, they insist on being employed by industries located in the communities. Nowadays, it is difficult to find trust worthy honest, decent, responsible and hardworking youth who is focused and have their priorities right. Youths seem to see responsibility as too tasking and diminishing. Thereby, they refuse to execute such task with or without pay depending on the situation. Sometimes, they demand for unreasonable payment for the job they want to do. The values of the society have been misplaced. The problem of incapability of performing task effectively or shying away from work could be as a result of improper home training, lack of discipline, defiance, laziness and lack of self-confidence Ofem and Ajayi (2008) have stated that "lack of humanitarian and social welfare, lack of good governance, corrupt practices of government officials, inadequate training programmes, unemployment, inadequate recreational facilities and lack of quality education amongst others the reasons for incessant youth restiveness". The relentless youth restiveness in Nigeria can be attributed to the following:

\section{Poor Governmental Policies}

When a government policy is not favourable to a people, it tends to breed opposition from the masses because they feel oppressed and 
neglected. There is need for the government to study her masses and find out their pressing needs and ensure that it is meant. According to Oromareghake et al (2013), "the escalating state of violence between the Niger Delta youth and the Nigeria Government is that of the politics of access to the oil fund" In the developed world like the United States of America, an adult of 18 years and above is given accommodation and allowances when he/she does not have a job. A similar act should be passed in Nigeria. This will reduce the youth restiveness as they will have means to take care of themselves until they have something meaningful to do. When appropriate laws are not made, there cannot be growth and development in the country. A bad policy divides the nation, breeds youth restiveness, increases criminality, destroys societal and government structures. There is need for government in preparing a country's budget to equitably distribute her natural resources to avoid chaos.

Bad government policies are associated with bad governance. Bad governance infringes on the masses" fundamental human rights, promotes corruption, is not accountable to the masses, it is an irresponsible government and lacks proper transparency. In the tenure of a bad government, there is usually increase in crime rate, no freedom of speech, centralization of government is practiced, misappropriate of funds and mismanagement of resources amongst others. These attributes lead not only to the dissatisfaction of the youths but the masses in general.

\section{Lack of Job Opportunity}

In Nigeria today, the growing rate of unemployment is alarming. According to Onuba (2019), "the labour statistics report released by the National Bureau of Statistics showed that the number of Nigerians unemployed rose from 11.92 million in the first quarter of 2017 to 13.58 million and 15.99 million in the second and third quarters respectively". Ozohu-Suleiman (2006) observed that "Nigerian youth 
are trapped by unemployment." Most Nigerians are depending solely on either the government or oil companies for employment. Nigerians are failing in using their initiatives, skills resources and knowledge to start businesses and create job opportunities for the masses. The youths are also not taking the empowerment programmes seriously so that they can be self-employed. The dependency rate on government and few oil companies is raising a lot of agitations which is detrimental to the wellbeing of the nation.

Zakaria (2006) strongly believes that the absence of job opportunities in developing countries is responsible for youth restiveness with disastrous consequences. Government has not put in enough functional structure in place to provide jobs for the masses. There is the need for government to be involved in home made goods and ensuring that there are local industries around the countries where youths can be employed while revenues will also be generated for the country. This will help engage the youths and curb idleness that would have ordinarily led to evil vices.

The inability of the youths to have or create jobs makes them to be vulnerable to unreasonable politicians, religious fanatics and greedy individuals. They are used to carry unlawful activities with a stipend reward. Zakaria (2006) believes that "the rising tide of unemployment and the fear of a bleak future among the youth in African countries have made them vulnerable to the manipulations of agents provocateurs".

\section{Poor Standard of Living}

Poor standard of living contributes to youth restiveness. There is a common Nigeria proverb which states that "a hungry man is an angry man". When people cannot meet their basic needs of food, clothing and shelter, they are regarded as poor. Poverty is a poor standard of living condition. Aworawo (2000) agreed that there is a connection between poverty, unemployment, discrimination, and youth 
restiveness in relation to violence by youth towards the Nigeria government. The gap between the rich and the poor is usually large. The poor feels dejected, oppressed, dehumanized and segregated. Most youths, rather that partake in responsible jobs to get funds, they look for avenues to make quick monies. These make the youth to be involved in criminal activities that will bring funds to them and their families, no matter the consequences. Today, the cases of internet fraudsters (yahoo boys), deceitful activities (419), kidnapping and ritual activities are on the increase. All these lead to insecurity in the state.

\section{Inadequate Educational System}

Education plays a vital role in the growth, development and stability of a country. The basic knowledge for human development educationally and socially is acquired in an educational environment. The problem with the Nigeria educational system today is that they lack infrastructural facilities, lack equipment, lack quality teachers and do not follow the scheme of work especially in the rural areas.

Most youths in the rural areas do not go to school because they cannot meet the financial obligation to attain educational qualifications; some affect those in the urban areas. This will not help the country. In government schools in Nigeria, payments are still made. Government should encourage all to attend school by ensuring that there is free Education at the primary and secondary levels. At the University level, the fees should be greatly reduced.

The irony of these is that those that graduate still find it difficult to get jobs. This further encompasses the problems of their families and the youth. The government and the masses must work as one to ensure that investments in education are promoted in the country to cub this menace. Wordpress (2014), stated that, "Quality education has a direct bearing on national prestige, greatness, and cohesion. The knowledge and skill that young people acquire help 
determine their degree of patriotism and contribution to national integration and progress". Population reference Bureau, 2006 stated that "Between 2000 and 2004, about 30 percent of Nigerian youth between 10 and 24 were not enrolled in secondary school (population Reference Bureau, 2006). "This could be as a result of unreasonable cost in acquiring Education. This situation is not healthy for Nigerians.

\section{Poor Infrastructural Facilities}

In general, Nigeria has poor infrastructural facilities. These lack of facilities occurred as a result of unequal distribution of the national resources, misappropriation of funds and mismanagement of funds. Nigerians lack educational facilities, clean water, roads, electricity, and medical facilities amongst others. The strive to get these facilities in place can also lead to youth restiveness.

\section{Lack of Information}

Information is vital in taking crucial and important decision. Wrong information can be very detrimental to decision making process as it will mislead all to making wrong decision. Therefore, part of the cause of the youth restiveness in the society is as a result of wrong information delivered to the youth. These will make them to be aggressive and partake in violent protest as the case may be. The studies of Hidon and Ahiauzu (2005) in Niger Delta revealed that lack of communication and insufficient information flow can lead to youth restiveness. Therefore, leaders and members of the public should be careful with the type of information they share as information can build and also destroy. People should interact to share information. Lack of communication, inadequate and wrong information can lead to emergence of youth restiveness. 


\section{The Effects of Youth Restiveness}

Youth restiveness is a problem to communities and the country at large. The way and manner through which youth try to achieve their goals by agitation have reduced societal progress and cripple productive level in the society. In the course of struggling to protect their interest through the use of youth restiveness, they create more problems for themselves. These acts push them to commit crimes that they could be apprehended for, thereby worsening their situations. The effects of youth restiveness are:

\section{Increasing Crime}

According to Schaefer 2005, crime is a violation of criminal law for which some governmental authority applies formal penalties. Laws divide crimes into various categories. Depending on the severity of the offense, the age of the offender, the potential punishment, and the court that holds jurisdiction over the case. Crime is dangerous to all aspect of society; be it political, social, economic, religious or educational. Crime prevents good relationships between countries, it leads to destruction of lives and properties, it dampens the spirit of both local and foreign investors to invest in the country, and this increases insecurity and leads to underdevelopment.

Increased criminal activities have occurred from youth restiveness. The desire for youths to have better lives without having meaningful skills and educational knowledge to meet up has pushed them into criminality. Crime is a risk to societal safety.

\section{Unsecured Environment}

The illegal activities of the youths are as a result of uncertainty or anxiety. They lose self confidence in themselves. In the Niger-Delta, everyone seems to be cautious of their environment because of fear of being kidnapped, and also to escape from any violence that may likely arise. According to Oromareghake et al (2013), the oil boom has 
increase violence in the Niger delta, which in 2006 resulted in the reduction of Nigeria's oil export by $25 \%$. The general insecurity caused by the activities of the restive youths and the security agencies costs the country treasury billions of naira each year. It should also be noted that in order to control unrest and boost production, the government has adopted strategies ranging from direct negotiation with the Militants to all-out Military assaults on them. However, these methods have not been successful". The youth are not relenting in the vandalization of pipelines. Oromareghake et al (2013) stated that "securing the pipelines and other oil and gas assets in the country has become a heavy burden to the government". Until date, the government still spends a lot on security to protect the country's natural resources from youth restiveness, bunkering and smugglers activities. The problem of insecurity has driven away both foreign and local investors thereby increasing unemployment rate. This in turn, will encourage youths to partake in illegal activities thereby creating problems for the society.

\section{Poor Financial State}

Pettinger (2017) stated that "a low rate of economic growth can cause higher unemployment". When there is inflation, mismanagement of funds and misappropriate of funds in a country, there is bound to be financial crisis. When there is no proper circulation of funds in the society, there will be reduction in the demand for goods by the masses and industries will require few services. This will have adverse effect on the youths. If a country experiences decline in her finances, some industries will be shut down, thereby making many workers to become jobless.

\section{Increased Underemployment}

The unemployment rate in Nigeria is increasing rather than decreasing. This is affecting the youths tremendously that they are 
willingly to partake in plans that are detrimental to themselves and the society. Kazeem (2017) stated that,

National Bureau of Statistics (NBS) (2016) pegs the unemployment rate at $14.2 \%$ in the last quarter of 2016, up from $13.9 \%$ in the preceding quarter. It's the ninth consecutive quarter that the unemployment rate has increase. Employment has faltered as businesses struggled amid Nigeria's first recession in two deceases. These companies' dependent on foreign transactions are also suffering due to a critical shortage of dollars. In May 2016, nearly a million people applied for ten thousand $(10,000)$ listed positions in the Nigerian police force. Also in November 2016, the Federal Tax agency received 700,000 applications for 500 advertised positions. Majority of Nigerian youths within the median age of 21 are most affected. Fraudulent schemes have strived with millions looking to make quick buck in the absence of gainful employment".

\section{Rebellious Communal Behaviour}

Rebellious communal behaviour by the youth is caused by incessant demands for their interest to be met. The Advocates for the advancement of Youth Development Initiatives (AAYDI) 2012, have stated that the activities of youth restiveness have affected the country negatively through low production of goods and services through disorder, by disrupting law and order in the society, e.g. militancy. Increased crime rates, increase in intra-ethnic and religious conflict, disturbing investors and other numerous criminal tendencies. The problems associated with rebellious communal behaviour are marginalization, unemployment, exuberance, poverty and poor educational opportunities.

Youth restiveness has led to destruction of oneself because when they are caught by the Government law agencies, the 
punishment could be devastating. They could be sentenced to life imprisonment, they could be sentenced to death, it may lead to their imprisonment, and such activities can also lead to fight among the youth causing disability amongst others. The restiveness of youth affects social and economic activities negatively thereby leading to hardship.

Vandalization of pipelines by youth affects societies negatively, especially it destroys vegetation. The spillage on the community's river destroys their water and fishes. Youth restiveness has led to loss of lives and poverty people now live in fear as a result of youth insurgence.

\section{Control of Youth Restiveness in Enhancing Public Peace}

The control of youth restiveness has become eminent. Public peace in a community or state is very necessary for development and growth, hence the need to curb vices such as youth restiveness has lead necessitated the following:

Favourable Governmental policies: a favourable government policy would give the people a sense of belonging. There is need for Nigeria's resources to be protected by policy guided solutions (Reje, 2013). It would eliminate youth restiveness and other related hostilities. The needs and interest of the masses will be met. This will further lead to the national growth and development of the country. Peace will then reign.

Job Opportunities: Having a job makes youths to have selfsatisfaction. Government and members of the public are encouraged to engage investments that will help produce employment. Government needs to put enough functional structure in place to provide jobs for the masses. There is the need for government to be involved in home made goods and ensuring that, the local industries 
around the countries are established, where youths can be employed while revenues can also be generated for the country.

Good Standard of Living: Good standard of living contributes to economic growth. When people can meet their basic needs of food, clothing and shelter, they are regarded as living well. Poverty and its related consequences should be curbed by government ensuring better living through functional structural programmes.

Standards Education System: The educational system in the countries should be improved. In Nigeria, there is need for good educational infrastructural facilities and the necessary materials for learning. Education at the primary and secondary levels should be free. Universities fees should be reduced to the barest minimum. These will encourage more people to attend schools and illiteracy will be reduced.

Improve Infrastructural Facilities: In general, Nigeria needs to improve her infrastructural facilities. Nigerians should have basic educational, clean water, reads, electricity, and medical facilities amongst others. The government should ensure that we have all these in place.

Adequate Information: There should be proper dissemination of information so that the right decisions will be taken to improve the lives of all and the societies at large. Information has been likened to a stimulus that can condition a person to certain behaviour (Curras, 1987). Information has a way of prompting humans to behave negatively or positively. There should be proper medium through which the youths can be informed politically, economically, socially, educationally and medically for their overall wellbeing and that of the 
state. According to Onyekpe (2007), Youth Restiveness can be curbed by:

Making the youth understand that the future is theirs to maintain and not to destroy. They should be made to know that the choices and decision they make will affect their future. The present youths should have a sense of history especially in the noble contributions of other youths to the development of Nigeria, in comparison with the ignorable role of many youths today. The awareness of them to embrace the rule of law and democratic ideals is very essential. They should be liberated psychologically and mentally from the control of self-seeking business and political elites. Youths should be encouraged to raise issues relating to unresolved problems of nation should be mobilized against abuse of the system through sanction. Also, they should be sensitized towards seeking greater employment and educational opportunities as a means of redirecting their energy and ideas from anti-social activities to creative efforts.

Availability of Well Furnished Libraries: The works of Omotayo (2005) and Echezoma (2007) have shown the relevance of the use of library in enhancing of public peace and communal unity. Encouraging youths to get useful information from libraries can control youth restiveness generally. The essence of libraries includes attaining, processing, preserving, and disseminating varied information. The duty of the library is to educate and enlighten the youth and the entire community. Anasi, (2010) stated that libraries serve communities by "presenting them with factual information that will guide their actions and help make good conclusion that will promote peace. This will reduce the amount of youth violence, acrimony, and confrontation". 
Omotayo (2005) opined that "in war situations in enlightened societies, the use of libraries increases, as users flock to libraries to find information to guide them. Information that can promote peace, unity, progress, peaceful co-existence, and harmonious relationship among all the communities must therefore be available in libraries. Librarians, therefore, in promoting access to this information, act as agents of the promotion of communal peace and reconciliation. Libraries are positioned as hubs for formal and informal learning. School libraries, academic libraries, and public libraries support the education of the youth. Information obtained from libraries can change the behaviour, attitudes, and mindset of youth".

Elegbeleye (2005) strongly believes that leisure facilities provide flexibility for youths to let off stress and become less tense. Anasi (2010) stated that "libraries should not only be stocked with educational materials, they should have recreational facilities where pent-up energies and emotions can be dissipated". The need for recreational facilities and centers for youth relaxation is very essential to help curb stress. Stress can lead to depression and can also arouse violence.

Ndagana and Ogunrombi (2006) stated that, "Libraries create opportunities for youth employment. For instance, in Nigeria, the University of Lagos Library and Federal University of Technology, Yola, Library employs students under a work study scheme to perform routine jobs." Many Universities including the Federal University of Petroleum Resources, Effurun also have such work scheme to help engage students in more educative task to remove their minds from violence and to ease sufferings by the students economically. The students employed execute their tasks with eagerness and passion. They ensure any task given to them is timely executed. Anasi (2010) also observed that "youths who are gainfully employed rarely participate in antisocial activities and that library also organize seminars and workshops on career development. These 
programmes provide career guidance and counselling and will help reduce the number of idle, frustrated youth who roam the stress aimlessly, and who might at the least provocation, takes recourse to violence". It is not surprising that libraries perform such functions as they do have academics working in the library.

\section{Recommendations}

The study has analyzed the causes and effects of youth restiveness. Therefore, for peace, meaningful progress and development to be achieved, the following recommendations are required to curb youth restiveness:

Government should create job opportunities for its citizens. In Nigeria, there is the need for government and citizens to engage in local productions of goods. This will lead to building of industries and attracting manpower. Effective and meaningful empowerment programmes should also be adopted in the state so that those that could not be employed by government, private and nongovernmental organizations can be self-employed. This attainment of free qualitative education in Nigeria will help improve the reasoning capacities of her citizens. In essence, there will be proper dissemination of information that will promote peace or ensure a state of tranquillity. The government of countries, Nigeria in particular should make favourable polices in the distribution of national resources. This will help eradicate marginalization, oppression, neglect and underdevelopment.

Policies to prevent religious, political and ethnic crisis should be made and adhered to strictly. Generally, there should be proper implementation of law that will cater for the prevention of the cases and effect of youth restiveness. Lectures, workshops and seminars should be organized for the youths to educate, enlighten and expose them they will not be used by miscreant for selfish interest. 
The educated citizens should through interaction and socialization help to enlighten and influence the ideas of the uneducated ones in the society, rather than it being the other way round. Corruption in Nigeria should be curbed so that misappropriate and embezzlement of funds can be stopped. The government agencies such as the Economic and Financial Crime Commission (EFCC), responsible for ensuring the prevention of misappropriation and embezzlement of funds in Nigeria should be properly equipped to encourage them in performing their task effectively. Monies meant for development will then be used appropriately. Such actions will encourage stability in the country. Government should work earnestly towards curbing poverty by directing their attention to adopting functional alleviation programmes that will help the masses to have good standard of living. The use of rewards and punishments by parents, academic and vocational institutions, government, private and nongovernment organizations can serve as checks to the attitudes and behaviour of youths.

Government should endeavour that the composition of political parties and the processes involved in elections do not involve the use of hoodlums and thugs as youths are usually found within this group. Those seen as hoodlums and thugs should be rehabilitated. Any violence from such groups, her members should follow the due process of the law. There should be well established rehabilitation centres in the country to help redirect the youths and make them understand the standards expected of them as citizens

\section{Conclusion}

Youth restiveness should not be taken likely as it has constituted fear, torments, insecurity and uncertainty in the lives of Nigerians. The restiveness of youth has promoted conflicts and has affected the peaceful coexistence of citizens as well as foreigners. The development of the country has been crippled by destructions of properties. The involvement of youths in criminal activities has further enhanced conflict and insecurity. Poor governmental policies, lack of job opportunities, poor standard of living, inadequate education system, poor infrastructural 
facilities, lack of information among others have been identified in this research work as reasons for youth restiveness. This problem has effected all in the society as the situation is disheartening. The attempt of government and non-governmental organization to handle this restiveness needs to be improved and new strategies to solve these oblivious problems need to be analyzed and adopted for social peace to exist. The authorities in the state should endeavour to provide lasting solutions to these problems by introducing futuristic and practical strategies that will help curb dissatisfaction, marginalization and discrimination of youth. The national interest and needs of youths and other members of the society in conformity with the laws of the country should be met.

Also, the need to engage the youths in gainful employment and empowering youth effectively should be necessitated. This will help in proffering solutions to some of the problems being experienced in the society. Nevertheless, parents, guardians and teachers also should play significant roles in educating, enlightening, guiding and protecting our youths. All members of the society and government should eradicate selfish desires and work towards attaining public peace. The idea of this study is to give the understanding that once the causes of an unpalatable situation like youth restiveness has been identified, analyzed and controlled, only then can peace, progress, development and growth accomplished.

\section{Raymond Akpokighe Political Science Department College of Education, Agbor Delta State raymondowell@gmail.com \&}

Austine Ejovi, PhD

Political Science Department College of Education, Agbor scottmarvelshawn@yahoo.com 


\section{References}

Administrator (2012) "Youth Restiveness and unemployment in Nigeria. "The Advocates for the Advancement of Youth Development initiatives. Retrieved from :http://www.advocates youth.org/index.php?option.

Amorawo, D. (2000) Mal-Distribution and Poverty as Factors in the crisis of the Nigeria State. The Constitution: A journal of Constitutional Development 1 (2): 1-13

Anasi N.I. (2010) Curbing Youth Restiveness in Nigeria: The Role of Information and Libraries. Library Philosophy and practice. Retrieved from: https://www.researchgate.com

Crossman A. (2019) Understanding Conflict Theory. Retrived from: https://www.thought co.com conflict-theory-30326622.

Curras, E. (1987) Information as a fifth vital element and its influence on the culture of the people. Journal of Information Science 13 (3): 27-36

Echezona, R.I. (2007). The Role of Libraries in Information Dissemination for conflict resolution, Peacer Promotion and Reconciliation. African Journal of Libraries, Archieves, and Information Science 17 (2): 143-152.

Elegbeleye, O.S. (2005) Recreational Facilities in Schools: A Panacea for Youths' Restiveness. Journal of Human Ecology 18 (2): 93-98.

Ifidon, S.E., \& Ahiazua, B. (2005) Information and Conflict Prevention in the Niger Delta Region of Nigeria. African Journal of Libraries, Archives, and Information Science 15 (12): 125-132.

Ikpa I. and Igbo H.I (2013) Causes, Effects and Ways of Curbing Youth Restiveness in Nigeria: Implications for Counseling. Journal of Education and Practice 4 (6): 131-137.

Kazeem Y. (2017) Nigeria's unemployment Problem in showing No signs of slowing down. Retrieved from: https://qz- 
com.cdn.ampproject.org/v/s/qz.com/africa/999641/theunemploymentrate-in-nigeria-has-climbed-for-nineconsecutive-quarters/amp/?amp-js-v-a2amp-gsa-1\&usqpmq33AQA\#referrer-

https \%3A\%2F\%2Fwww.google.com\&amp-if-from\% 20\%25

Merton K.R. (1930) Strain Theory. Retrieved from: https//www.britannica.com/topic/strain-theory-spcoplogy.

Ndagana, B.L., \& Ogunromi, S.A. (2006) Blazing the Trial in Poverty Alleviation among students in Nigeria: The Federal University of Technology, Yola Library Philosophy and Practice 9 (Available: http:unllib.unl.edu/LPP/ndagana.htm..

Nsidibe A.U., Emaimo I.E., and Amah M.W. (2017) Implications of Youth Restiveness on Sustainable Development in Nigeria. South-South Journal of Culture and Development vo. 19 (1).

Ofem, N.I., \& Ajayi A.R. (2008) Effects of Youth Empowerment Strategies on Conflict Resolutions in the Niger Delta of Nigeria: Evidence From Cross River State. Journal of agriculture and Rural Development 6 (1,2): 39-146.

Omotayo B.O. (2005) Women and Conflict in the New Information Age: Virtual Libraries to the Rescue. A paper presented at the world Library and Information congress: $71^{\text {st }}$ Ifla General Conference and council August $14^{\text {th }}, 2005$, Oslo, Norway.

Onuba I. (2019) Trackling Unemployment through Entrepreneurship. Retrieved from: https: www.punchng.com/ taclkingunemployment-through0entrepreneursip/amp.

Onyekpe N. (2007) Managing Youth at Election. The Constitution of a Journal of constitutional Development 7 (1): 76-87

Oromareghake P.., Arisi R.O., Igho O.M. (2013). Youth Restiveness and Insecurity in Niger Delta: A Focus on Delta State. Retrieved From. https://globaljornals.org/GJHSS Volume 13/6-Youth.restivess-and Insecurity.pdf. 
Ozohu-Suleiman A. (2006) The Nigerian Youth in Compemtporary Political Development: Relevance, Challenges and Role Expectation. The Constitution: A Journal of Constitutional Development 6 (4): 97-111.

Pettinger T. (2017) Low Economic Growth and unemployment. Retrieved from: https://www.economicsHelp.org/Blog/10142 unemployment/Law-Economic-Growth-Unemployment.

Reje (2013) in Nsidibe a.U., Emaimo I.E., and amah M.W. (2017). Implications of Youth Restiveness on Sustainable Development in Nigeria. South-South Journal of culture and Development Vo. 19 (1)

Schaefer, (2005) Sociology. Nineth Edition. New York: Published by McGraw Hill.

Steemit (2018) Youths Restiveness: Its Causes, Effects and solutions. Retrieved from: https//wwwsteemit.com.

Wordpress (2014) Identify and Discuss the causes of Youth Restiveness in a particular Community in Nigeria.Retrieved from: https://hyattractions-wordpress.com.cdn. amppropject. org/v/s/hyattr actions.wordpress.com/2014/08/26/identifyand-disuss-the-causes-of-youthrestiven ess-in-a-particularcommunity-in-nigeria/amp/?amp-js-v-a\&ampgsa-1\&usgpmg331AQANaoh-15625043771138\&ccsi=17referrerhttps\%3A.

Yusuf A.Y. (2013) Youth Restiveness: Nigeria's security and Sustainable Development. Retrieved from: https://www/researchage.com/youth-restiveness.

Zakaria Y. (2006) Youth, Conflict, Security and Development. Available: https://www.realityof aid.org/roareport.php?tableroa2006\&id $=6$. 